\title{
Anti-Jewish Legislation in the Middle Ages
}

In contrast to today's conception of a unified and uniting legal system, it was common for medieval societies to have several legal systems "at work" at the same time. Some of these legal authorities followed an hierarchical order, such as imperial/royal law that stood above the legislation enacted by territorial princes (at least in theory), who, as town lords, in return could change, overturn, or dictate municipal law. Parallel to these secular legal systems, church law was enforced by an equally graded system of hierarchies, while the vast field of customary laws is particularly difficult to grasp due to its vast diversity and mostly oral tradition. Inhabitants of medieval cities and rural communities were therefore subjected to several legal systems: the general law of the country (often a non-codified customary law), the municipal law of the respective city, several sets of ecclesiastical regulations, and depending on their profession, they could be subjected to regulations of a specific organisation (e.g., universities or craft guilds).

This legal pluralism applied to Jews as well-they were granted their main legal standing from the respective ruler (see below); furthermore, they were permitted to enact their own halachic legislation within their communities. Their particular legal status, however, did not mean that Jews were exempt from other jurisdictional systems. They bought and sold their estates and properties according to the respective municipal and/or customary laws, paid and received dues and rents, and appeared as plaintiffs and defendants before all kinds of courts, showing them as more than passive recipients: they were active players who were not only aware of their legal circumstances but were also able to navigate within these frameworks. ${ }^{1}$

Anti-Jewish legislation is therefore only a part of medieval Jewry laws, and a part that existed parallel, and often in contrast to a neutral, or even positive legislation. It is also only a part of medieval anti-Jewish thought and agenda to which it contributed both ideas and measures to act upon. This essay cannot and does not claim to cover anti-Jewish legislation in medieval Europe exhaustively; in particular, the very diverse municipal and customary laws will be presented with a focus on the Ashkenazi regions of the Holy Roman Empire.

1 Cf. B. Wiedl, “...und kam der jud vor mich ze offens gericht. Juden und (städtische) Gerichtsobrigkeiten im Spätmittelalter,” Mediaevistik. Internationale Zeitschrift für Interdisziplinäre Mittelalterforschung 28/2015 (2016): 243-68.

Ә OpenAccess. () 2021 Birgit Wiedl, published by De Gruyter. (cc) BY-NC-ND This work is licensed under the Creative Commons Attribution-NonCommercial-NoDerivatives 4.0 International License. 


\section{Church Legislation}

Based on the Pauline concept of the Jews' special role in Christian salvation history, their role as witnesses of the past and their forthcoming conversion that would announce the end of times meant that their survival was necessary until Doomsday, a concept that was mainly stipulated by Church Father Augustine (d. 430). ${ }^{2}$ Thus, papal protection of the Jews was deemed essential already by the sixth-century's Pope Gregory I in his condemnation of forced baptism, who, in the form of the Sicut Iudeis bull, would grant the Jews the right to practise their religion uninhibited and would shield them from forced baptism, from violence against their lives, synagogues, and cemeteries, as well as (added later) from ritual murder accusations (blood libel). ${ }^{3}$ The second concept is rooted in the damnation of the Jews in St. John's Gospel: in the refusal of Christ, Jews had proved to be the eternal enemies of Christ and Christendom and had thus been condemned to perpetual servitude. ${ }^{4}$ These two contradictory positions and their potential reconciliation were discussed in theological writing from late antiquity onwards, such as by Augustine who emphasised the Jews' function as witness bearers for the Old Testament but also underlined their (deliberate) obduracy and blindness toward Christ.

Many of the anti-Jewish sentiments that found their way into canon law and ecclesiastical legislation had their roots in late antique and early medieval synods and councils ${ }^{5}$ as well as papal decrees and letters. Up until the twelfth century, ecclesiastical legislation did not claim immediate jurisdiction over Jews (and other non-Christians) but tried to achieve control over them by regulating the Christians' conduct: by inducing fear of the scheming and malevolent Jews

2 For the vast literature on Augustine, see the fundamental study by J. Cohen, Living Letters of the Law: Ideas of the Jew in Medieval Christianity (Berkeley: University of California Press, 1999); and the two contributions by T. Raveaux, "Das Judenbild bei Augustinus," and C. Cluse, "Töte sie nicht!' Echos der Augustinischen Theologie über die jüdische 'Zeugenschaft' im Mittelalter,” both in Augustinus - Christentum - Judentum: Ausgewählte Stationen einer Problemgeschichte, ed. C. Müller and G. Förstner (Würzburg: Augustinus bei echter, 2018), 49-80 and 113-55, both with further literature.

3 First issued by Pope Callixtus II in ca. 1120, most medieval popes re-issued the Sicut iudeis bull, cf. S. Simonsohn, The Apostolic See and the Jews: Documents, 492-1404 (Toronto: Pontifical Institute of Mediaeval Studies, 1988), 68, 143, 211, 242, 245-46, 249, 254, 260, 265, 396, 430, 507.

4 Cf. A. S. Abulafia, Christian-Jewish Relations, 1000-1300: Jews in the Service of Medieval Christendom (London: Routledge, 2011).

5 Cf. F. J. E. Boddens Hosang, Establishing Boundaries: Christian-Jewish Relations in Early Council Texts and the Writings of Church Fathers (Leiden: Brill, 2010). 
but also by threatening those Christians who kept company with the Jews with dire consequences up to excommunication.

In the mid-twelfth-century Decretum Gratiani, a compilation of canon law, ${ }^{6}$ the many articles concerned with Jews $^{7}$ cover a wide range of regulations that could be in some parts inconsistent, and even contradictory, due to the collection's compiled nature. The Jews' continuous existence and the necessity of their protection is affirmed. The topics of Christian slaves in Jewish households and conversion are treated with the interest of the church in mind (e.g., awarding child custody to the converted spouse) and forbid (and, if, occurring, sanction) apostasy. In particular, conversion was a main concern of the church in many aspects - the (il)legality of forced baptism and whether to allow those affected to return to their old faith; whether converted Jews should, as per Jewish law, lose their possessions, and who was to care for them if they did; and whether to regard recidivists as heretics: all these questions would remain key issues for ecclesiastical thought and legislation until and beyond the Late Middle Ages. ${ }^{8}$ While not all of these discussions were inherently anti-Jewish, they perpetuate the Christian fantasies of lapsed converts or even fake conversions, as well as

6 In addition to the basic survey by H. Schreckenberg, Die christlichen Adversus-Judaeos-Texte und ihr literarisches und historisches Umfeld, 3 vols. (Frankfurt/Main: Peter Lang, 1991-1999), F. Lotter has given an overview over ecclesiastical legislature concerning Jews from the Merovingian era to the High Middle Ages, published posthumously in Aschkenas 28, no. 2 (2018): "Die Stellung der Juden im Merowingerreich nach dem Zeugnis der Synodalakten," 175-216; "Die Juden im Decretum Gratiani," 217-81; "Die Juden in den späteren kanonistischen Rechtssammlungen,” 282-336. Cf. also A. S. Abulafia, “Gratian and the Jews," Jaarboek Thomas Instituut te Utrecht 36 (2017): 9-39. Medieval canon law and its manifold concerns with Jews (as well as Pagans and Muslims) has become a core source for studies on post-colonialism and othering, for example, J. Lopez, "Beyond Eurocentrism and Orientalism: Revisiting the Othering of Jews and Muslims through Medieval Canon Law,” Review of International Studies 42, no. 3 (2016): $450-70$.

7 See the tabellary overviews by Lotter, “Juden im Decretum Gratiani," 265-81, with references to earlier regulations.

8 Much has been published on both Jewish conversion itself and the Christian concepts, see among many S. Goldin, Apostasy and Jewish Identity in High Middle Ages Northern Europe: 'Are you still my brother?', trans. J. Chipman (Manchester: Manchester University Press, 2014); A. Haverkamp, "Baptised Jews in German Lands during the Twelfth Century," in Jews and Christians in Twelfth-Century Europe, ed. M. A. Signer and J. Van Engen (Notre Dame: University of Notre Dame Press, 2001), 255-310; J. Shatzmiller, "Jewish Converts to Christianity in Medieval Europe 1200-1500," in Cross Cultural Convergences in the Crusader Period: Essays Presented to Aryeh Grabois on His Sixty-fifth Birthday, ed. M. Goodich, S. Menache, and S. Schein (New York: Peter Lang, 1999), 297-318. On return and conversion to Judaism, see more recently P. Tartakoff, Conversion, Circumcision, and Ritual Murder in Medieval Europe (Philadelphia: University of Pennsylvania Press, 2020). 
Jewish proselytism. The fateful late medieval view of forced baptism as legitimate, and the subsequent damnation (and execution) of returned converts, had its roots in these earlier discussions.

However, the decretum also incorporated central anti-Jewish ideas, which had been previously discussed in theological writings, such as the Jews' obduracy and deliberate blindness toward Christ, ${ }^{9}$ a concept that was translated into visual renditions in form of the blindfolded, defeated Synagoga who, together with the triumphant Ecclesia, would grace numerous medieval churches and manuscripts and thus made it accessible to and understandable for the populace. ${ }^{10}$ The decretum warned against any too-close Jewish-Christian interaction, such as consulting with Jewish doctors, and simply living and dining together. Particularly the consumption of "Jewish" (i.e., kosher) food by Christians had already been a major concern of councils and synods of the early Middle Ages and would reappear in later councils and synods that cautioned Christians against buying or accepting wine and meat from Jews, with the warning that the Jews would seek to poison them. ${ }^{11}$ Ample room is given to the concept of the Jews as the killers of Christ, dealing not only with the theological idea of the Jews' perpetual damnation as a just punishment for their inexcusable misdeed but also its "real-world" translation: that this punishment should be meted out by another people, namely God's new people, that is, the Christians. ${ }^{12}$ Together with excommunicated individuals, heretics, slaves, and heathens, Jews were subsumed under the dishonourable who were denied the right to sue against clerics/Christians, under the proposition that plaintiffs had to be of equal or higher standing to the defendant, a concept that ties in with the idea that

9 See particularly Peter the Venerable's Against the Inveterate Obduracy of the Jews, trans. and annotated by I. M. Resnick (Washington DC: Catholic University of America Press, 2013).

10 Literature on Ecclesia and Synagoga, particularly as statues, is vast; see N. Rowe, The Jew, the Cathedral, and the Medieval City: Synagoga and Ecclesia in the Thirteenth Century (Cambridge: Cambridge University Press, 2011); A. Weber, "Glaube und Wissen-Ecclesia et Synagoga," Wissenspopularisierung: Konzepte der Wissensverbreitung im Wandel, ed. C. Kretschmann (Berlin: Akademie Verlag, 2003), 89-126; B. Wiedl, "Jews and Anti-Jewish Fantasies in Christian Imagination in the Middle Ages," in Imagination and Fantasy in the Middle Ages and Early Modern Time: Projections, Dreams, Monsters, and Illusions, ed. A. Classen (Berlin: De Gruyter, 2020), 578-84, 589-95.

11 Cf. C. Magin, "Wie es umb der iuden recht stet": Der Status der Juden in spätmittelalterlichen deutschen Rechtsbüchern (Göttingen: Wallstein, 1999), 332-43; D. M. Freidenreich, "Sharing Meals with Non-Christians in Canon Law Commentaries, Circa 1160-1260: A Case Study in Legal Development," Medieval Encounters 14 (2008): 41-77; I. M. Resnick, "Dietary Laws in Jewish-Christian Polemics: A Survey," Studies in Jewish-Christian Relations 6 (2011): 1-15.

12 Lotter, "Juden im Decretum Gratiani," 250-52. 
Jews should not hold power over or assume higher positions than Christians. ${ }^{13}$ Several of the conclusions presented in the decretum are openly hostile: Jews were not the sons of Abraham but of the devil-if not in blood, then in their deeds; they are not merely as bad as sodomites but worse. ${ }^{14}$

From the late twelfth century onwards, papal legislation expanded its claim to include non-Christians living among Christianity in their jurisdiction. ${ }^{15}$ The provisions of the Third Lateran Council (1179) show the transition state: Christians living in Jewish households were to be excommunicated and Jews were not allowed to employ Christian servants. To emphasise the higher standing Christians had, Christian testimony in court should be of higher value than Jewish testimony. The secular authorities were charged with protecting converts who were not to lose their possessions.

With the rule of Pope Innocent III (1198-1216), the Augustinian concept of the Jews' perpetual servitude was transferred from its theological into the legal, economic, and social domain where it would be put into practice within the framework of Jewish-Christian interaction. ${ }^{16}$ This new interpretation was first verbalised in a letter from Innocent III to two French bishops in which he not only emphasised the yoke of Jewish servitude, which they were never allowed to discard, and the need for their gratitude, but translated these ideas into political reality by employing the French king and his nobility to carry out the regulations and curb the Jews' excesses. ${ }^{17}$ This shift in interpretation, along with the church's newfound attempts of jurisdiction over the Jews, would serve to enhance the conflict between church and secular rulers who themselves lay claim to the lordship over the Jews.

Perhaps the most fateful milestone in anti-Jewish church legislation were the regulations of the Fourth Lateran Council (1215), in the course of which the doctrine of transubstantiation was defined, which would impact the anti-Jewish narrative of host desecration. Whereas many of the council's provisions were drawn from older legislation, such as the prohibition of entrusting Jews with public of-

13 The various canons compiled in the Decretum are somewhat inconsistent, some of them include the right to sue if said person had suffered damage in person, cf. Magin, "Wie es umb der iuden recht stet," $210-13$.

14 Lotter, "Juden im Decretum Gratiani," 253.

15 On the development of this idea, see Magin, "Wie es umb der iuden recht stet," 23-26; cf. also A. Fidora, "Latin Talmud and the Extension of Papal Jurisdiction over Jews," medieval worlds: comparative \& interdisciplinary studies 11 (2020): 159-60.

16 Magin, "Wie es umb der iuden recht stet," 21; Abulafia, Christian-Jewish Relations, 74.

17 Cf. Schreckenberg, Adversus Judaius, 2:408-11; J. Heil, "Gottesfeinde"-“Menschenfeinde": Die Vorstellung von jüdischer Weltverschwörung (13. bis 16. Jahrhundert) (Essen: Klartext, 2006), 189-90. 
fices ${ }^{18}$ that should prevent Jews from holding power over Christians, Lateran IV aimed directly at the Jews themselves, their behaviour, and their public appearance: Jews were forbidden to demand excessive interest rates and any interest from crusaders; they were to stay indoors during Holy Week to refrain from mocking the mourning Christians; voluntary converts should not return to their Jewish faith (implying though that forced baptism was still considered invalid); and Jews as well as Muslims were required to wear distinguishing clothing, mainly to prevent "involuntary" sexual encounters with Christians. ${ }^{19}$ The canons of Lateran IV were included in the Liber Extra (1234), the canonical collection of Pope Gregory IX that was to replace all former collections as a legal textbook of canon law.

After Lateran IV, regional councils and synods disseminated and further differentiated the canons and translated their rather general and still somewhat abstract concepts into practical advice on how to control (or, ideally, prevent) Jewish-Christian personal, social, and neighbourly interaction, thus immediately interfering with Jewish daily life. ${ }^{20}$ Christians were forbidden to work and particularly live in Jewish households; they were warned against taking medicine from

18 The regulation dates back to the Third Council of Toledo (598), see Schreckenberg, Adversus Judaius, 1:418-19. Jews were (much to the church's chagrin) active in various capacities, see M. J. Wenninger, "Juden als Münzmeister, Zollpächter und fürstliche Finanzbeamte im mittelalterlichen Aschkenas," in Wirtschaftsgeschichte der mittelalterlichen Juden: Fragen und Einschätzungen, ed. M. Toch (München: Oldenbourg, 2008), 121-89; for Jews as mint-masters, cf. E. Haverkamp, "Jüdische Münzmeister und ihre Münzen im Kontext von Handel und Geldhandel," in Geprägte Bilderwelten der Romanik: Münzkunst und Währungsräume zwischen Brixen und Prag, ed. F. Hofer et al. (Bolzano: Athesia Tappeiner Verlag, 2017), 155-91; E. Haverkamp, "Jewish Images on Christian Coins: Economy and Symbolism in Medieval Germany,” Jews and Christians in Medieval Europe: The Historiographical Legacy of Bernhard Blumenkranz, ed. P. Buc, M. Keil, and J. Tolan (Turnhout: Brepols, 2016), 189-226; and as tax collectors at the Hungarian and Austrian courts, cf. N. Berend, At the Gate of Christendom: Jews, Muslims and 'Pagans' in Medieval Hungary, c. 1000-c. 1300 (Cambridge: Cambridge University Press, 2001), 101-8, 127-31; E. Brugger, "Von der Ansiedlung bis zur Vertreibung: Juden in Österreich im Mittelalter," in Geschichte der Juden in Österreich, ed. E. Brugger et al. (Wien: Ueberreuter, 2013), 141-42.

19 Specific clothing was often used as a distinguishing and/or social marker, cf. R. Jütte, "Stigma-Symbole: Kleidung als identitätsstiftendes Merkmal bei spätmittelalterlichen und frühneuzeitlichen Randgruppen (Juden, Dirnen, Aussätzigen, Bettler),” Saeculum 44, no. 1 (1993): $65-89$.

20 Cf. the collection Corpus der Quellen zur Geschichte der Juden im spätmittelalterlichen Reich, coord. A. HAVERKAMP and J. MüLLER, Trier, from 2011 onwards, http://www.medieval-ashkenaz. org/quellen/1273-1347/sk01.html. All further quotations of SK01 (plus the respective number) refer to this collection, the corresponding entries have been authored by R. Richtscheid. 
or visiting Jewish doctors, ${ }^{21}$ buying the Jews' (poisoned) meat and, of course, from having sexual intercourse with Jews. ${ }^{22}$ Jewish space and movement within a city was limited and controlled: Jews were banned from places of particular close encounters, namely bath houses and taverns, and from social acts that carry a strong ritual connotation, such as dining, celebrating, and dancing with Christians. ${ }^{23}$ On Good Friday,or whenever the Eucharist (i.e., the Host wafer) was carried past, Jews were forbidden to leave their houses, or even to look through their windows, and during Lent, they were not allowed to transport meat. The limitations of public appearance reflects several anti-Jewish ideas: the spiteful Jew who mocks the Christians during their high holidays but also the Jewish seducer who tries to con Christians into breaking their religious rules. The Christian fantasy of Jews seducing Christians appears also in the church's mistrust concerning conversion that went two ways: Jews were suspected of hindering baptisms and were thus ordered to not interfere, particularly with female and juvenile converts, but were also thought to actively proselytize. To prevent any doubt of their own faith in Christians (and, ultimately, conversion to Judaism), Jews were forbidden to conduct religious debates with "simple" Christians, including illiterate priests. ${ }^{24}$ In addition to regulating Jewish life and behaviour, the church extended its grasp onto the synagogues. Communities were barred from erecting new synagogues and were forbidden to alter the height or size of those already in existence. ${ }^{25}$

Lateran IV had introduced the mandatory distinguishing marker that Jews (and Muslims) had to wear to canon law, yet had lacked any specific description of this item. In central Europe, most provincial and regional synods took up this idea of a "Jewish" attribute to make them distinguishable from Christians. ${ }^{26}$ Any "disguise" was seen as particularly improper and audacious: the "blasphemers

21 Councils of Wroclaw and Vienna 1267, cf. E. Brugger and B. Wiedl, Von den Anfängen bis 1338, vol. 1 of Regesten zur Geschichte der Juden in Österreich im Mittelalter (Innsbruck: StudienVerlag, 2005), 59-61, no. 45; Trier [1278], SK01, no. 2.

22 Wroclaw and Vienna 1267, cf. Brugger and Wiedl, Regesten, 1:59-61, no. 45; Trier 1310 (sexual intercourse of a Christian man with a Jewish, Saracen, or Pagan woman) SK01, no. 9.

23 Wroclaw and Vienna 1267, Brugger and Wiedl, Regesten, 1:59-61, no. 45. For Christians as guests at Jewish festivities cf. M. J. Wenninger, "als etlich kristen lüt...mit dien Juden getanzet hant: Über die Teilnahme von Christen an jüdischen Festen im Mittelalter," Aschkenas 26, no. 1 (2016): 37-67.

24 Wroclaw and Vienna 1267, Brugger and Wiedl, Regesten, 1:59-61, no. 45, Mainz 1274/75 and 1310, SK01, no. 1, no. 10, illiterate priests: Trier [1278], SK01, no. 2.

25 Wroclaw and Vienna 1267, Brugger and Wiedl, Regesten, 1:59-61, no. 45, Bressanone 1318, SK01, no. 11, and possibly Wroclaw 1331, SK01, no. 12a (unclear due to loss of text).

26 Aschaffenburg 1292, SK01, no. 5, Bressanone 1318, SK01, no. 11. 
of Christ" even dared to wear cowls like clerics, the constitutions of the bishop of Wroclaw complained in 1331, and explicitly forbade Jews who wore such a cowl to participate in the public space of the market. ${ }^{27}$ While most of these synods merely refer to "distinguishing garbs," the Councils of Wroclaw and Vienna, held a few months apart in 1267 by the papal legate Guido, defined the object in detail: the pileus cornutus, the pointed Jewish hat, a headgear the Jews had "worn in earlier times in these regions, but had dared to discard." While the Jewish hat therefore acquired the more derogatory connotation of a mandatory attribute in the context of church law and was used as a symbol of shame also in Christian context, ${ }^{28}$ it is important to note that the hat appears to have stemmed from Jewish traditional costume, ${ }^{29}$ and served in central European Christian art also as a neutral, even appreciatory indicator of a person's Jewishness (e.g., the famous depiction of the "Jewish" poet Süßkind of Trimberg); ${ }^{30}$ it was also used by Jews as a self-identifier in manuscripts and on seals. ${ }^{31}$

27 Wroclaw 1331, SK01, no. 12a.

28 It was common to "mark" Christian women who had sexual relationships with Jewish men, cf. N. Schnitzler, “'Contra Naturam'-Sexuelle Devianz und jüdisch-christliche Koexistenz im Mittelalter," in Wechselseitige Wahrnehmung der Religionen im Spätmittelalter und in der Frühen Neuzeit, ed. L. Grenzmann et al. (Berlin: De Gruyter, 2009), 275; S. Burghartz, "Juden - eine Minderheit vor Gericht (Zürich 1378-1436)," in Spannungen und Widersprüche: Gedenkschrift für František Graus, ed. S. Burghartz et al. (Sigmaringen: Jan Thorbecke, 1992), 235.

29 The debate to what extent Jews wore any headgear as part of their daily apparel is still ongoing, cf. S. Lipton, Dark Mirror: The Medieval Origins of Anti-Jewish Iconography (New York: Metropolitan Books, 2014), 16-45; E. Baumgarten, Practicing Piety in Medieval Ashkenaz: Men, Women, and Everyday Religious Observance (Philadelphia: University of Pennsylvania Press, 2014), $176-78$.

30 Cf. UB Heidelberg, Cod. Pal. germ. 848, fol. 355r, https://digi.ub.uni-heidelberg.de/diglit/ cpg848/0705.

31 E.g., in the famous zoocephalic Birds' Head Haggadah, https://www.imj.org.il/en/collec tions/199815, and in the Leipzig Machsor, see K. Kogmann-Appel, A Mahzor from Worms: Art and Religion in a Medieval Jewish Community (Cambridge: Harvard University Press, 2012), and illustration here: http://davidkultur.at/artikel/das-8222ritual-des-ersten-lernens-zu-schawuot-im-mit telalter (M. Keil, “Das 'Ritual des ersten Lernens' zu Schawuot im Mittelalter," David. Jüdische Kulturzeitschrift 18, no. 69 [2006]: 5-7). For a Jewish seal with a Jewish hat, see the seals of the Regensburg Jew Peter bar Mosche, A. Lehnertz, Corpus der Quellen, 2014, JS01, no. 1, http://www.medieval-ashkenaz.org/JS01/CP1-c1-02q7.html, and the Augsburg Jew Lamblein, JS01, no. 8, http://www.medieval-ashkenaz.org/JS01/CP1-c1-02q2.html. A. Lehnertz, Judensiegel im spätmittelalterlichen Reichsgebiet: Beglaubigungstätigkeit und Selbstrepräsentation von Jüdinnen und Juden, 2 vols. (Wiesbaden: Harrassowitz, 2020). 
In western Europe and Hungary, ${ }^{32}$ the synods opted for a much more discriminatory identifier: in 1227, the Synod of Narbonne prescribed a distinguishing marker in the form of an oval badge, one finger in width and half a palm in height. In several shapes, and partly with the addition of the mandatory yellow (and sometimes red), the badge soon made its way into royal legislation: in 1228, King James I of Aragón ordered the Jews to wear it in public, more closely defined by John I in 1393 as a yellow and red wheel along with specific garments; ${ }^{33}$ similarly, Alfonso X of Castile and Leon demanded distinguishing markers in 1263/65 (which were implemented only later). King Louis IX of France imposed a fine on all Jews who appeared in public without a rouelle (wheel) on their clothing in 1269 (which was reconfirmed in several church councils), while England's Jews were ordered by both royal (see below) and church law to wear a badge of yellow felt in the shape of two joined tables, mimicking those on which Moses had received the commandments. Hungarian Jews were required to wear a red, round cloth sown onto the left side of their outer garment (while Muslims and other non-Christians should wear a yellow mark) according to the Council of Buda in 1279. ${ }^{34}$ While depictions of Jews in French, Spanish, and English art show these identifying markers, it is however unclear whether it actually had been translated into the Jews' everyday appearance. Already the Council of Zamora (1313) complains about the order not having been enforced in Castile; and in many instances, Jews were given special permission to discontinue wearing it. With (Anti-)Pope Benedict XIII, the badge was introduced into papal legislation in 1415, defining it as a yellow and red badge, which Jewish men were required to wear on their breast and Jewish women on their forehead. The bull of Benedict XIII (who was of Spanish origin and at the time back in Aragón) had limited influence in central Europe: the synod of Salzburg in 1418 reconfirmed the Jewish hat as compulsory (and added a bell for Jewish women), and even the Council of Basel/Florence, which during its long term (1431-1449) shifted from the more pro-Jewish stance of Martin V to a stricter policy (perhaps under the influence of Spanish delegates), ${ }^{35}$ again referred to an unspecified "garment that distinguishes them from Christians." However, in the course of the fifteenth century, the Jewish hat would disappear from central Europe and be replaced with the yellow badge (often introduces by

32 The oft-cited "badge" for Erfurt in 1294 refers to the dress code implemented in the synod of Aschaffenburg (see above) of 1292 that only refers to "signs or garments" Jews should be required to wear.

33 Schreckenberg, Adversus Judaius, 3:412.

34 Ibid., 3:279-80.

35 Ibid., 3:494. 
secular rulers); its appearances in German art at around 1470 clearly illustrate this change. ${ }^{36}$

Among the many anti-Jewish stereotypes ecclesiastical (and other) authors disseminated, the image of the Jewish usurer appears surprisingly scarcely in canon law and church legislation (but had a great influence on French and English royal policy, see below). Despite the canonical ban on interest-taking, ${ }^{37}$ Christian moneylending business, both official and concealed, existed and drew scathing criticism from ecclesiastical authors. In that context, Jews were used as a negative foil, particularly in, but not limited to (polemical) preaching, where the Christian usurer was depicted as even more despicable than his Jewish counterpart. ${ }^{38}$ With the late twelfth century, anti-usury agitation not only gained momentum but turned to direct attacks against the Jews, who with their presumed greed and lack of mercy toward their Christian victims literally embodied the equation of usura with robbery and fraud. Yet, regulations concerning Jewish interest-taking were rarely introduced in canon law: Lateran IV complained about the Jews' "grave and excessive interest rates" but sanctioned only their Christian business partners while the Second Council of Lyon (1274) promoted the expulsion of foreign usurers regardless of their faith (but was nevertheless utilised as a justification for the expulsion of Jews). ${ }^{39}$ Likewise, the provincial

36 For example, on the broadsheet that illustrated the alleged host desecration in Passau (1477/ 78), see https://upload.wikimedia.org/wikipedia/commons/1/11/Host_desecration1.jpg., and on a portable altar from Lower Austria, cf. Wiedl, "Jews and Anti-Jewish Fantasies," 596-97, with fig. 6.

37 For a summary of this vast topic, see S. Schima, "Die Entwicklung des kanonischen Zinsverbots. Eine Darstellung unter besonderer Berücksichtigung der Bezugnahmen zum Judentum,” Aschkenas 20 (2010): 239-79.

38 Cf. C. Cluse, "Zum Zusammenhang von Wuchervorwurf und Judenvertreibung im 13. Jahrhundert," Judenvertreibungen in Mittelalter und Früher Neuzeit, ed. F. Burgard, A. Haverkamp, and G. Mentgen (Hannover: Hahnsche Buchhandlung, 1999), 135-63; C. Cluse, "Jewish Moneylending in Dominican Preaching, Confession, and Counselling: Some Examples from Later Medieval Germany," in Dominikaner und Juden. Personen, Konflikte und Perspektiven vom 13. bis zum 20. Jahrhundert/Dominicans and Jews: Personalities, Conflicts, and Perspectives from the 13th to the 20th Century, ed. E. Füllenbach and G. Miletto (Berlin: De Gruyter, 2015), 195-23; G. Mikosch, Von alter ê und ungetriuwen Juden: Juden und Judendiskurse in den deutschen Predigten des 12. und 13. Jahrhunderts (München: Wilhelm Fink, 2010).

39 Such as the (in)famous canon Usurarum voraginem of the Second Council of Lyon (1274), cf. R. Dorin, "Canon Law and the Problem of Expulsion: The Origin and Interpretation of Usurarum Voraginem (VI 5.5.1),” Zeitschrift der Savigny-Stiftung für Rechtsgeschichte: Kanonistische Abteilung 99, no. 1 (2013): $129-61$. 
synods of the thirteenth and fourteenth centuries mostly resorted to a general damnation of usurers and their clientele. ${ }^{40}$

The imperial privilege for the Jews to clear themselves of the suspicion of having accepted stolen goods as pledges by taking an oath ("Statute of the Market," see below), drew fierce criticism from the church primarily for one reason: popes Innocent III and Alexander IV, along with theologians, had been enraged by the idea that this "very old but truly diabolic law" would allow Jews to "be fattened and revel in luxury" (Peter the Venerable) since it enabled them to accept (stolen) liturgical objects as pledges. ${ }^{41}$ Worries that sacred objects (and, with them, Christ himself) would suffer horrible mistreatment at the hands of the Jews, already expressed by sixth-century's Gregory I, ${ }^{42}$ were linked with scathing critiques of the Jews' greed and the unjust law that made it impossible to demand the object back. Provincial synods more closely defined the objects that were under no circumstances to be pawned to Jews: particularly chalices, ${ }^{43}$ but also crucifixes, books, and vestments ${ }^{44}$ yet only rarely tried to abolish the statute itself. ${ }^{45}$

40 Trier [1278], SK01, no. 2. St. Pölten 1284, Brugger and Wiedl, Regesten, 1:79, no. 65, only the synods of Wroclaw and Vienna repeated Lateran IV's canon and added the secular rulers' duty to protect his Christian subjects against the Jewish frauds. The synod of Lüttich 1288 forbade advocates to represent usurers, heretics, and Jews against Christians unless explicitly ordered to do so by a judge, SK01, no. 4.

41 Cf. J. Shatzmiller, "Church Articles: Pawns in the Hands of Jewish Moneylenders," in Wirtschaftsgeschichte der mittelalterlichen Juden: Fragen und Einschätzungen, ed. M. Toch and E. Müller-Lackner (München: Oldenbourg, 2008), 93-102, with examples from France; J. R. Müller, "Zur Verpfändung sakraler Kultgegenstände an Juden im mittelalterlichen Reich: Norm und Praxis," in Pro multis beneficiis-Festschrift für Friedhelm Burgard: Forschungen zur Geschichte der Juden und des Trierer Raums, ed. S. Hirbodian et al. (Trier: Kliomedia, 2012), 190 -93; Magin, "Wie es umb der iuden recht stet," 361-66; on Peter the Venerable cf. Schreckenberg, Adversus Judaius, 2:180 -96, quote on page 190; Cohen, Living Letters, 245-70; I. M. Resnick, "Peter the Venerable on the Talmud, the Jews, and Islam," Medieval Encounters 24 (2018): $510-29$.

42 Cf. Shatzmiller, "Church Articles," 95-97.

43 Cf. Müller, “Verpfändung,” 190 - 93. Synods of Liegnitz 1285, SK01, no. 3a, Mainz 1302, SK01, no. 7, and Strasbourg [1341] and 1345, SK01, no. 13, no. 14.

44 Mainz 1302, SK01, no. 7. Books were a particularly sensitive topic for both sides, cf. Müller, "Verpfändung," (throughout the article); B. Wiedl, "Sacred Objects in Jewish Hands: Two Case Studies," Jews and Christians in Medieval Europe: The Historiographical Legacy of Bernhard Blumenkranz, ed. P. Buc, M. Keil, and J. V. Tolan (Turnhout: Brepols, 2016), 72-75, from a Jewish perspective cf. M. Keil, "Heilige Worte, Schriften des Abscheus: Der Umgang mit Büchern als Paradigma des jüdisch-christlichen Spannungsverhältnisses,” Text als Realie, ed. K. Brunner and G. Jaritz (Wien: Austrian Academy of Sciences Press, 2003), 49-61.

45 Liegnitz 1285, SK01, no. 3a. 
So that no Christian or Jew could plead ignorance, the council of Aschaffenburg ordered any rector of the province of Mainz should on four Sundays a year promulgate these ordinances in the vernacular during Mass. ${ }^{46}$ Did those proclamations, however, mean that canon law had a huge impact on the living conditions and everyday life of medieval Jews? Repeated complaints about a lack of compliance (from both Christians and Jews) with the regulations suggest otherwise, yet the role of anti-Jewish resolutions in church law in the perpetuation of negative preconceptions of the Jews should not be underestimated, even if antiJewish sentiment was more successfully transmitted for the general public by means of narratives such as ritual murder allegations (blood libels) and accusations of host desecration. Later councils of the fourteenth and fifteenth centuries added only a few new ideas, such as the council of Basel (1431-1449), that in their canones regarding the Jews of 1434, subjected the Jews to missionary sermons they had to listen to on a regular basis. A particular emphasis was put on as complete a separation as possible of Jewish and Christian lives: apart from the (already much repeated) ban on social encounters such as bathing and dining, Jewish living quarters were to be segregated from those of the Christians and as distant from churches as possible. In the thirteenth century, Jewish living space was, and remained, in the city centres, and the idea of a complete spatial separation had appeared only once, in the Council of Wroclaw in 1267 that even stipulated a physical barrier in form of a fence, wall, or trench between the two areas. ${ }^{47}$ After the pogroms of the mid-fourteenth century, however, a tendency to relocate the Jews' allocated quarters to the fringes of the urban area is noticeable in several European towns. ${ }^{48}$

46 Aschaffenburg 1292, SK01, no. 5.

47 J. Heil, "Die propagandistische Vorbereitung des Ghettos: Diskussionen um Judenquartiere," in Frühneuzeitliche Ghettos in Europa im Vergleich, ed. F. Backhaus et al. (Berlin: trafo, 2012), 155 points to an interesting bull by Pope Clement IV of the same time that only cautioned the Jews of Gniezno against erecting higher and more luxurious houses but clearly acts on the assumption that they remained in their living quarters. Cf. also H.-J. Becker, "Die Stellung des kanonischen Rechts zu den Andersgläubigen: Heiden, Juden und Ketzer," in Wechselseitige Wahrnehmung der Religionen im Spätmittelalter und in der Frühen Neuzeit, ed. L. Grenzmann et al. (Berlin: De Gruyter, 2009), 117-18.

48 Cf. H.-J. Gilomen, "Spätmittelalterliche Siedlungssegregation und Ghettoisierung, insbesondere im Gebiet der heutigen Schweiz," in Abgrenzungen-Ausgrenzungen in der Stadt und um die Stadt, vol. 3 of Stadt- und Landmauern, ed. Institut für Denkmalpflege an der ETH Zürich (Zürich: Hochschulverlag AG an der ETH Zürich, 1999), 85-106; Heil, "Vorbereitung des Ghettos," 159-60. 


\section{Legislation of the Secular Rulers}

From the ecclesiastical standpoint of the mid-twelfth century onwards, secular rulers would be obliged to carry out papal and other church regulations, thus recognising the church's supreme claim to lordship over the Jews. Many secular rulers were therefore reluctant to concede to the church's claim of supremacy, both as a tool in the ongoing power struggle between secular and ecclesiastical power, and because several of the church's provisions would run against their primary interest in the Jews, that is, their financial gain. Therefore, secular rulers not only procrastinated in carrying out the church's regulations but openly counteracted them, including a not-too-small number of ecclesiastical princes who, acting as rulers of their territory and (secular) lords over their Jews, followed their primary interest in the well-being of their country. The archbishop of Mainz, for example, abrogated his own command of a Jewish dress code in 1294, which he had enacted at the provincial council of Aschaffenburg only two years earlier, in order to facilitate an agreement between the municipality of Erfurt and the local Jewish community. ${ }^{49}$

The legal standing granted to medieval Jews by their respective secular rulers had a far more immediate impact on their everyday life since it defined the framework within which Jewish existence was possible. Its main features, developing both under the influence of and in competition with ecclesiastical regulations, were far more positive toward the Jews. Already in the Carolingian era, protection privileges were granted to individual Jews (but also other individuals). The imperial privileges of the late eleventh century to Rhineland communities ${ }^{50}$ granted wide-ranging protection of Jewish life, property, and business, integrated ideas of Jewish law and adapted the general idea of protection as a core ideal of the ruler's duties toward his subjects.

In the wake of a ritual murder accusation in Fulda in 1235, Emperor Frederick II extended the privilege to all Jews of the Holy Roman Empire and defined the Jews' status as servi camerae nostri ("servants of our chamber"), making them part of the imperial treasure, as did, in his legal succession, the terri-

49 Cf. M. Lämmerhirt, Corpus der Quellen, 2015, TW01, no. 58, http://www.medieval-ashkenaz. org/TW01/CP1-c1-00os.html; R. Richtscheid, "Judenbetreffe in Synodal- und Konzilsstatuten (1237-1347)," Corpus der Quellen, issued 2011, accessed October 27, 2020, http://www.medie val-ashkenaz.org/SK01/einleitung.html.

50 Granted to the Jews of Speyer (1180, by Bishop Rudolf) and Worms (1090, by Emperor Heinrich IV), cf. M. Toch, Die Juden im mittelalterlichen Reich (München: Oldenbourg, 2013), 46-47. 
torial princes who obtained the "right to the Jews" (Judenregal) in the course of the fourteenth century. ${ }^{51}$ The Jews of France and England remained more closely bound to their respective kings due to the limited development of territorial lords. The majority of regulations enacted by secular rulers were protective privileges and aimed at promoting settlements by providing living conditions under which the (subsequently taxed) Jewish communities could flourish; anti-Jewish ideas can therefore rather be found in the rulers' political actions than in their legislation, in selective measures that were often directed at specific individuals or groups and were, at least up until the mid-fourteenth century, predominantly (though not exclusively) politically and/or economically motivated. Thus, the political and economic development of the respective territory should be factored in in an analysis of these measures. Anti-Jewish decrees or actions of a ruler do not necessarily signify a general anti-Jewish disposition or policy: the same ruler could agree to a persecution in one city whose loyalty he wanted to gain and punish another for "damaging" his Jews (and thus his income), or annul an allegiant noble family's debts and assist the Jews to collect their debts from another he deemed disloyal. With the late thirteenth century, the focus on promotion and protection shifted toward a more openly expressed economic interest which, in the course of the following century, turned into financial exploitation that was executed with measures of increasing violence, such as by the Habsburg dukes who incarcerated their Austrian Jews in 1377 and only released them after receiving ransom, or by a series of debt annulments issued by King Wenceslaus I in 1385 and 1390 that had devastating consequences for Jewish business. ${ }^{52}$

The dependency on the ruler's protection placed all European Jews in a particularly precarious position should this protection wane, end, or even be turned against them. Whereas in the territories of the Holy Roman Empire, the rulers' predominant financial interest-and thus an interest in thriving Jewish communities-made them the target of ecclesiastical polemics, which accused them of favouring the Jews in order to profit off their usury, the royal policy in France and England was more in accordance with church opinions and, while not exclusively aimed at the Jews, sought to limit moneylending. In France, the longstanding Capetian anti-usury policy reached its peak under the reign of exceedingly (and

51 The discussion on Jewish service and Kammerknechtschaft is vast, cf. Toch, Die Juden im mittelalterlichen Reich, 48-49 (also on Judenregal) and 104-7.

52 Cf. Brugger, “Ansiedlung,” 220; K. Hruza, “Anno domini 1385 do burden die iuden ... gevangen. Die vorweggenommene Wirkung skandalöser Urkunden König Wenzels (IV.),” in Wege zur Urkunde, Wege der Urkunde, Wege der Forschung: Beiträge zur europäischen Diplomatik des Mittelalters, ed. K. Hruza and P. A. Herold (Wien: Böhlau, 2005), 117-67. 
demonstratively so) pious King Louis IX whose fierce anti-Jewish stance also brought a heightened urgency to the crown's efforts to encourage the conversion of Jews (and Muslims) ${ }^{53}$ and promoted the Disputation of Paris with its ensuing damnation and burning of the Talmud in $1242 .{ }^{54}$ While (re)structuring France's financial management under a tight control of the crown, Louis reinforced his anti-usury policy by severely cutting down moneylending. The king's hostile policy culminated in the 1252 eviction decree for those Jews who would not abandon moneylending, the second expulsion of the French Jews after 1182 (after ritual murder accusations). ${ }^{55}$ When the king's advisors contradicted the banishment, arguing that since moneylending itself was necessary, it would be better if the Jews, who were condemned anyway, did it than the Christians, Louis countered that the Jews' presence in France was his responsibility, and thus their usury would affect his soul. ${ }^{56}$ In the following years, several confiscations of Jewish property filled the royal treasury, and as of 1269, French Jews were required to wear an identifying marker in shape of a yellow wheel (see above). After having been expulsed for financial reasons in 1306, King Louis X allowed the Jews to return in 1315 under his protection of their lives and property, albeit with severe restrictions on settlement (limited to twelve years individually) and behaviour according to the ideas of canon law: a mandatory badge, no disputing matters of faith, and the continuing damnation of the Talmud. Similar inconsistencies resulting from a mixture of secular with church law can be seen in several of the western European countries, such as, Alfonso X's Siete Partidas for his Kingdoms of Castile and Leon (1263/65, achieving legal status in 1348) that included protection provisions as well as anti-Jewish regulations from canon law (no Christian servants, no shared meals, baths, and sexual encounters, no new synagogues). ${ }^{57}$

The Jews of England were not only under a tight royal control but incorporated into the crown's administration (which surpassed any secular administration on the continent in terms of efficiency and literacy). As early as late twelfth

53 Cf. W. C. Jordan, The Apple of His Eye: Converts from Islam in the Reign of Louis IX (Princeton: Princeton University Press, 2019).

54 Cf. Cohen, Living Letters, 317-25 on the church's part, particularly that of Nicolas Donin and Pope Gregory IX; cf. also Fidora, "Latin Talmud."

55 Cf. R. Chazan, The Jews of Medieval Western Christendom, 1000-1500 (Cambridge: Cambridge University Press, 2006), 146-50.

56 For a survey, still see the fundamental study by W. C. Jordan, The French Monarchy and the Jews: From Philip Augustus to the Last Capetians (Philadelphia: University of Pennsylvania Press, 1989); further R. Chazan, Reassessing Jewish Life in Medieval Europe (Cambridge: Cambridge University Press, 2010), $130-31$.

57 Schreckenberg, Adversus Judaius, 3:287-90. 
century, Jewish taxes and legal cases were administered by a specific office, the royal Exchequer of the Jews, and while not anti-Jewish in its purpose, its tallagerolls house is one of the most strikingly anti-Jewish visual renditions: the infamous drawing of the Norwich Jews Isaac, Mosse-Mokke, and Abigail surrounded by demons. ${ }^{58}$ Having been granted privileges in the course of the twelfth century ${ }^{59}$-the right to their own oath and their own court, the right to move around freely, along with economic provisions-the English Jewry flourished, which lay in the interest of the King: having defined them as his own property enabled him to tax them without permission of the Parliament. While the growing antiJewish sentiments, particularly the emerging blood libel, which led to mob violence against Jewish communities, were still countered by royal protection orders up until the early 1200s, the influence of anti-Jewish legislation, mainly imported from canon law, grew. Already in 1218, the Council of Regency, under pressure from the papal legate, ordered the Jews to wear a distinguishing garb (yet allowed dispensations to be bought), which was repeated in the Statute of Jewry (1253) of King Henry III. This Statute clearly demonstrated the dominating influence of ecclesiastical canons. While defining the Jews' rights of settlement as only in effect if (economically) beneficial for the crown, for the most part it repeated (and specified) Lateran IV's regulations and included measures that, in other territories, were rather found in regulations of post-Lateran IV synods: separation in order to prevent any close contact, no hindering of conversions, no new synagogues, no religious debates and disparaging remarks regarding Christianity, no buying and consumption of meat during Lent. In addition, the statute reprimanded the English Jews to lower their voices in the synagogue so that Christians could not hear them, an instruction King Henry translated into reality in 1272, when he gave a confiscated London synagogue to the Friars of the Sack who had complained about the "continuous wailing" from their Jewish neigh-

58 The cartoon (British National Archives, Kew, E.410/1565, Rolls of the Issues of the Exchequer, Hilary Term 1233) can be seen here: www.nationalarchives.gov.uk/education/resources/medie val-mystery/; A. Bale, The Jew in the Medieval Book: English Antisemitisms, 1350-1500 (Cambridge: Cambridge University Press, 2006), 2-4. On Bale's not entirely unproblematic differentiation between medieval anti-Judaism and antisemitism and the role of actual presence of Jews as a distinguishing element, cf. ibid., 1-21. On the caricature, see also Lipton, Dark Mirror, $178-82$.

59 In the Leges Edwardi Confessoris, a collection of laws attributed to mid-eleventh century Edward I but not compiled until a century later, Henry I grants a series of rights to the London chief Rabbi Joseph and his followers. Translations and/or summaries of English Jewry-law have been provided in J. G. Hillaby and C. Hillaby, The Palgrave Dictionary of Medieval Anglo-Jewish History (London: Palgrave Macmillan, 2013), 17-37. 
bours. ${ }^{60}$ Jews were forbidden to enter churches and those Jews who lived outside of established communities had to obtain a royal licence. Henry's reinforced undertaking to promote conversion led to the foundation of the Domus conversorum, a London-based royal institution that took care of the newly converted. ${ }^{61}$ Henry's successor Edward I, also in the light of a declining economic importance of the Jews (who had been financially exploited by both Henry and Edward) took up a royal anti-usury policy that had until then only been preached by synods and clerics: in his Statute of 1275, he demanded that since "he had seen that divers evils and the disinheriting of good men of his land have happened by the usuries which the Jews have made in time past," Jews should completely abandon moneylending, even if this would hurt the crown's revenues. Under continuing ecclesiastical influence, he also enforced the separation of Jewish and Christian living spaces by banning Christians from living among Jews while restricting Jewish settlement to royal cities only, and confirmed the mandatory yellow felt marker in form of two joined table. ${ }^{62}$ Coin-clipping had become a major accusation against Jews (and Christians) over the past decades, and in 1278, all Jews of England were incarcerated due to this allegation, and many were subsequently executed. ${ }^{63}$ Twelve years later, in his eviction decree, Edward cited the unwillingness of the Jews, "maliciously deliberating among themselves," to comply to the 1275 terms and depressing his subjects even further so that he "by reason of their errors and to the honour of Christ, has caused the Jews to leave his realm as perfidious men." 64

The absence of anti-Jewish topics in (most of) the secular legislation of the Holy Roman Empire should not be taken for an absence of these ideas within

60 Cf. R. Stacey, "King Henry III and the Jews," Jews in Medieval Christendom: "Slay Them Not," ed. K. T. Utterback and M. L. Price (Leiden: Brill, 2013), 121-22. Jewish voices and the Hebrew language was frequently likened to a dog's bark; fifteenth-century German author Michael Behaim, among others, pretended to hear "wailing, hellish cries, and dogs' barks" from the synagogue, cf. Heil, “Gottesfeinde”-"Menschenfeinde,” 113; B. Wiedl, “Anti-Jewish Polemics in Business Charters from Late Medieval Austria," Medieval Worlds: Comparative \& Interdisciplinary Studies 7 (2018): 61-79.

61 Cf. L. Fogle, The King's Converts: Jewish Conversion in Medieval London (Lanham: Lexington Books, 2019). The English royal policy toward Jews has been interpreted in the context of postcolonial and race studies, mainly by G. Heng, England and the Jews: How Religion and Violence Created the First Racial State in the West (Cambridge: Cambridge University Press, 2019), and an outtake of her encompassing study The Invention of Race in the European Middle Ages (Cambridge: Cambridge University Press, 2018), 55-109.

62 Hillaby and Hillaby, Dictionary, 46-47.

63 Hillaby and Hillaby, Dictionary, 103-9; Fogle, King’s Converts, 41-42, 45; Heng, England, $39-41$, with further literature. Christians too were accused of coin-clipping.

64 Hillaby and Hillaby, Dictionary, 36-37. 
secular rule. The expulsion decrees clearly demonstrate how permeated the Christian mindset was with anti-Jewish ideas, how easily these accusations, from counterfeiting to ritual murder and host desecration, were utilised as weapons, as was blatant financial gain. When (later) Emperor Maximilian I gave in to the pressure of the Styrian Estates and his financial desires and evicted the Styrian Jews in 1497, he listed all the anti-Jewish stereotypes that had caused violence against the Jews throughout the Middle Ages: their crimes and duplicity, the ritual murders and host desecrations they continued to commit, their counterfeiting and deceitful business practises that had caused many a noble family to perish. A few years earlier, a host desecration allegation had resulted not only in the deaths of twenty-seven Sternberg Jews but was followed by the expulsion of the Jews from the north-eastern territories-apart from the dukes of Mecklenburg in whose territory Sternberg was located, also the duke of Pomerania, the archbishop of Magdeburg (who had served as a judge in the trial at Sternberg) and his suffragans, ${ }^{65}$ and the margrave of Brandenburg seized the opportunity, while circulating woodcuts, broadsheets, and incunables ${ }^{66}$ spread the "reason" for their anti-Jewish policy.

\section{Customary and Municipal Law}

\section{Customary Law}

The status of Jews in medieval customary law(s) is even more diverse than in other legislation and, due to an at best fragmentary tradition of written records, even less traceable. Therefore, single law codes will serve as examples of how anti-Jewish legislation was represented in customary law in the realm of the Holy Roman Empire. Customary law was recorded from the late thirteenth century onwards in Rechtsbüchern (legal codices) and Weistümern (collections of

65 Cf. F. Backhaus "Die Hostienschändungsprozesse von Sternberg (1492) und Berlin (1510) und die Ausweisung der Juden aus Mecklenburg und der Mark Brandenburg,” Jahrbuch für Brandenburgische Landesgeschichte 39 (1988): 7-26; V. Honemann, "Die Sternberger Hostienschändung und ihre Quellen," in Literaturlandschaften: Schriften zur deutschsprachigen Literatur im Osten des Reiches, ed. V. Honemann (Frankfurt/Main: Peter Lang, 2008), 187-216.

66 Already in 1492, the year of the alleged desecration and the trial, Magdeburg-based publisher Simon Koch printed an extensive rendition of the events, http://digital.staatsbibliothek-berlin. de/dms/werkansicht/?PPN=PPN656982853\&DMDID=DMDLOG_0000. The story became popular quickly and was included in the Schedelsche Weltchronik (Nuremberg Chronicle), an illustrated encyclopedia of world history, cf. B. Posselt, Konzeption und Kompilation der Schedelschen Weltchronik (Wiesbaden: Harrassowitz, 2015). 
oral legal traditions), compilations of a mostly "private" nature ${ }^{67}$ that reflect the customs of a locally restricted area in varying degrees of elaborateness; many of these codes exist in several renditions, which do not necessarily tally in their texts. ${ }^{68}$ Most of these compilations drew from a variety of legal codes: canon and ecclesiastical law as well as secular law was combined with customary laws of the respective territory, in addition to that, older compilations were copied and rearranged. Topics covered in ecclesiastical and secular law were commented on, in addition to that, customary law also deal in more detail with social, legal, and economic matters which were only touched upon in "official" legislation. In her standard work on the Jews' status in Rechtsbüchern, Christine Magin has categorised four main subject areas that are discussed in the legal codices: the social status of Jews; questions regarding conversion; procedural law; and Jewish trade and moneylending. All these topics were particularly controversial between ecclesiastical and secular legislation. ${ }^{69}$

Not all topics were presented with anti-Jewish intent, and compilers would deal with the same topic with varying attitudes. Already the question of the Jews' general status was discussed with various approaches: the Sachsenspiegel, perhaps the most influential “German” legal code, stressed the Jews' menial status yet also emphasised that harming a Jew would break the Imperial Peace. This refers to the inclusion of Jews in the First Imperial Peace of Mainz of 1103 that had put unarmed Jews, ${ }^{70}$ together with clerics, women, merchants, and other vulnerable groups, under the heightened protection of the emperor. In the Sachsenspiegel, this specific status is connected with a legendary origin-Josephus and the healing of Titus-that drew from both Christian and Talmudic sources. ${ }^{71}$ While other receptions focus on the anti-Jewish aspect of this legend and put it in context with the general idea of the Jews as a target of divine retaliation, the Sachsenspiegel links it with imperial legislation, and in further receptions of the Sachsenspiegel, this legend serves as the core explanation of the Jewish servitude

67 For a critique of this term and the problematic opposition of private and official, cf. Magin, "Wie es umb der iuden recht stet," 42-44, who emphasises that the compilations were often seen as official, valid law (with references to royal or imperial privileges and ordinances) and that the authors intended for their collections to be used and have a public impact.

68 Cf. ibid., 41-42.

69 Cf. ibid., 114.

70 On the debunking of the old perception that Jews were not allowed to bear arms, cf. the articles by C. Magin, “'Waffenrecht' und 'Waffenverbot' für Juden im Mittelalter: Zu einem Mythos der Forschungsgeschichte," and M. J. Wenninger, "Von jüdischen Rittern und anderen waffentragenden Juden im mittelalterlichen Deutschland," both in Aschkenas 13, no. 1 (2003): 17-33 and $35-82$.

71 Cf. Magin, “Wie es umb der iuden recht stet," 117-18. 
(although with some variations and inconsistencies): the Jews saved by Josephus were transferred to the royal treasury by Titus, where they remained in perpetual servitude, an interpretation that ascribes the origin of the Jews' legal status Roman emperors and puts the Holy Roman Emperor in their direct legal succession. Other compilations draw explicit connections between the Jews' (and in some, also the heathens') "guilt" that made them property of the ruler, and the rulers' interest in economic gain. ${ }^{72}$

Particularly references to a perceived favouritism of the Jews, mainly with regard to legal and economic privileges, were delivered with a clear anti-Jewish intent: the discussion surrounding the Statute of the Market, the right of the Jewish pawnbrokers to clear themselves of the suspicion of having accepted stolen goods as pledges by taking an oath. ${ }^{73}$ This right had first been granted in Emperor Henry IV's privilege for the Jews of Worms in 1090 and had been adapted by most territorial rulers of the Holy Roman Empire throughout the Middle Ages. ${ }^{74}$ Theologians had for a long time been labelling the statute particularly unjust since it allowed the Jews' business practices for which Christians were hanged (see above). ${ }^{75}$ These sentiments were reflected in several legal codes of customary law $^{76}$ that focused on this perceived injustice of the Jews' preferential rights, which the kings had "against justice" (wider recht) granted to them. ${ }^{77}$ "The cursed Jews have much better rights towards the Christians than the Christians towards the Jews," the Viennese Stadtrechtsbuch, a privately commissioned compendium of Viennese customary law, ducal privileges, and decisions of the city council mixed with passages from the Schwabenspiegel from before 1360, describes the situation: Lawful it might be, yet not proper and fair, and by the use of emotive language, the author follows to paint the Christian as the impecunious victim and the Jewish moneylender as the rapacious predator, utilising anti-Jewish stereotypes that were common in both narratives and imagery. ${ }^{78} \mathrm{Il}-$ lustrations could add another layer of anti-Jewish sentiment: the Jew who is

72 Cf. Magin, "Wie es umb der iuden recht stet," 124-35.

73 Cf. Toch, Die Juden im mittelalterlichen Reich, 109-10, also on the potential references to Jewish law and a Jewish participation in composing the privileges (with further literature).

74 For the ample discussion on the topic, see the overview by Magin, "Wie es umb der iuden recht stet," 352-400.

75 Cf. R. Chazan, Medieval Stereotypes and Modern Antisemitism (Berkeley: University of California Press, 1997), 51. Shatzmiller, “Church Articles,” 95-97 with examples from France; Müller, "Verpfändung sakraler Kultgegenstände," 190 -93.

76 Cf. Magin, “Wie es umb der iuden recht stet," 366-72.

77 Schwabenspiegel, cf. Müller, "Jüdische Pfandleiher," 453; Abulafia, Christian-Jewish Relations, 55.

78 Wiedl, “Anti-Jewish Polemics," 67-68. 
shown hanged or with his hand chopped off and a chalice next to him in several copies of the Sachsenspiegel evokes an image of a Jew being punished for his crime, lacking the qualifier of the written text (the possibility to present a warrantor). ${ }^{79}$ The Jews' right to appear as plaintiffs in cases of bodily harm was not denied (or even seen as understood), ${ }^{80}$ whereas the topic of Jewish testimony was mostly discussed in the (everyday) context of moneylending and pawn-broking. While most compliers merely gave an account of the possibilities of Jewish witness-bearing, several customary laws tried to exclude, or at least limit, Jewish testimony, and subsumed it under their criticism of the statute: the Jews had bought better rights for themselves from the king, summarizes the Schwabenspiegel. ${ }^{81}$ Apart from the Statute of the Market, the selling of specific goods, namely meat, by Jews was a main topic discussed in both customary and municipal law (and its broad intersections, see below).

Court procedures often included the taking of an oath as a means of proof and corroboration, and Jews were required to participate in this. ${ }^{82}$ As is the case with many other topics, the Judeneid cannot per se be seen as an element of Christian anti-Jewish action, as earlier studies have done. Oath-taking was common within the Jewish community (meaning, among Jews only), ${ }^{83}$ and

79 E.g. the Heidelberger Sachsenspiegel, UB Heidelberg, Cod. Pal. germ. 164, fol. 13v, http://digi. ub.uni-heidelberg.de/diglit/cpg164/0040; see Magin, "Wie es umb der iuden recht stet," 55; J. Shatzmiller, Cultural Exchange: Jews, Christians, and Art in the Medieval Marketplace (Princeton: Princeton University Press, 2013), 37-38; M. J. Wenninger, "Die Juden in den Bilderhandschriften des Sachsenspiegels," in Integration und Ausgrenzung: Studien zur deutsch-jüdischen Literaturund Kulturgeschichte von der Frühen Neuzeit bis zur Gegenwart. Festschrift für Hans Otto Horch, ed. M. H. Gelber, J. Hessing, and R. Jütte (Tübingen: Max Niemeyer, 2009), 12. The Sachsenspiegel depicts Jews in both neutral and derogatory contexts: while the aforementioned armed Jew does not carry any anti-Jewish associations, a Jew is utilised to impersonate doubt/bad faith to illustrate the reason of "doubts of rightful belief" in the context of reasons for a legitimate papal excommunication of the emperor, see Wenninger, "Juden in den Bilderhandschriften," 12-13.

80 Cf. Magin, "Wie es umb der iuden recht stet," 234.

81 Cf. ibid., 261.

82 Cf. G. Mentgen, "Judeneid," Handwörterbuch der deutschen Rechtsgeschichte (Berlin: Erich Schmidt Verlag, 2011), 2:1409-11; A. Schmidt, "so dir got helfe. Die Judeneide," in Juden in der deutschen Literatur des Mittelalters. Religiöse Konzepte-Feindbilder-Rechtfertigungen, ed. U. Schulze (Tübingen: Max Niemeyer Verlag, 2002), 87-105. For a brief summary on the vast discussion and its many remaining questions, cf. A. Lehnertz, "The Erfurt Judeneid between Pragmatism and Ritual: Some Aspects of Christian and Jewish Oath-Taking in Medieval Germany,” in Ritual Objects in Ritual Contexts, ed. C. D. BERgEMAnN and M. STÜRZEBECHER (Erfurt: Bussert \& Stadeler, 2020), 12-31.

83 Cf. Lehnertz, "Erfurt Judeneid," 16-18. 
also the specific set phrases Jews used in context of oath-taking at Christian courts had to draw from both Christian (customary) law and Jewish halachic law and custom to make the oath binding for both parties; rituals such as touching the doorknob of the synagogue had their counterpart in Christian ceremonies. ${ }^{84}$ Neither ecclesiastical nor secular legislation occupied themselves much with the subject, the former occasionally doubting a Jew's oath's validity, the latter including the Jews' right to swear on the Torah in their privileges. ${ }^{85}$ Several texts of Jewish oaths, as they were used in everyday practise, have been transmitted, ${ }^{86}$ and many legal codes and municipal laws from the mid-thirteenth century onwards included both the wording of the oath (as it was custom in the respective town or region) and descriptions of the accompanying ceremony. While most of these renditions were neutral, particularly the latter served as a medium for anti-Jewish derisions: the Jew shall stand on a sow's hide, stipulates the Schwabenspiegel, ${ }^{87}$ and illustrations in manuscripts ${ }^{88}$ not only translated the written word into visual stimuli but emphasised the connotation with one of the major anti-Jewish images of the Middle Ages, the Judensau. ${ }^{89}$ Other codes, such as the Weichbildvulgata, added specific clothing, often stressing that the Jew be barefoot, and a hat soaked in lamb's blood (or the sow's hide). ${ }^{90}$ An early sixteenth-century rendition of the Sachsenspiegel (that in its medieval text versions does not contain the oath) even specifies the sow's hide: it should

84 Cf. ibid., 12.

85 Magin, "Wie es umb der iuden recht stet," 280-87.

86 In addition to the Erfurt Judeneid, see the Jewish oaths of Krems and Vienna, cf. H. Voltelini, "Der Wiener und Kremser Judeneid," Mitteilungen des Vereins für Geschichte der Stadt Wien 12 (1932): 64-70. The Judeneid of Frankfurt exists in both a neutral and a derogatory version, cf. G. Grebner, "Haltungen zum Judeneid: Texte und Kontexte der Frankfurter Eidesformeln im 14. und 15. Jahrhundert," in '...Ihrer Bürger Freiheit.' Frankfurt am Main im Mittelalter, ed. H. Müller (Frankfurt/Main: Waldemar Kramer, 2004), 141-73; D. Schnur, Die Juden in Frankfurt am Main und in der Wetterau im Mittelalter: Christlich-jüdische Beziehungen, Gemeinden, Recht und Wirtschaft von den Anfängen bis um 1400 (Wiesbaden: Kommission für die Geschichte der Juden in Hessen, 2017), 272-77.

87 Cf. Schmidt, “Judeneide,” 89-102; Magin, “Wie es umb der iuden recht stet,” 291-97.

88 Schwabenspiegel, KBR Royal Library of Belgium, ms. 14689-91, c. 1425/50, fol. 204r, https:// uurl.kbr.be/1065739.

89 Cf. I. Shachar, The Judensau: A Medieval Anti-Jewish Motif and its History (London: Warburg Institute, 1974); B. Wiedl, "Laughing at the Beast: The Judensau: Anti-Jewish Propaganda and Humor from the Middle Ages to the Early Modern Period," in Laughter in the Middle Ages and Early Modern Times: Epistemology of a Fundamental Human Behavior, its Meaning, and Consequences, ed. A. Classen (Berlin: De Gruyter, 2010), 325-64.

90 Weichbildvulgata, Schmidt, "Judeneide," 102-3; Magin, "Wie es umb der iuden recht stet," 307-8; the majority of manuscripts do not contain this paragraph. 
stem from a sow that had farrowed within the past fortnight, and the hide should be cut along the back and spread out with the teats on the upper side. ${ }^{91}$ But, were these deeply humiliating and ridiculing rituals ever enacted? Dis ist ein fantasey, "this is fantasy," a commentator criticises the paragraph in his gloss to the Weichbildvulgata in 1557,92 and between the two versions of the Jewish oath of Frankfurt, only the one without the addition of the sow's hide was in actual use. ${ }^{93}$

Some legal codes discuss topics that are barely touched upon in others: for example, sexual relationships are not only discussed broadly in the Schwabenspiegel, its author also stipulates a much harsher punishment than the church: under canon law, only the female Christian offender is severely punished (flogging and expulsion) while the male Jew is due a monetary fine, the Schwabenspiegel wants both male Jew/female Christian and Jewess/male Christian to be bound together and burnt as a punishment for their adultery. In case of the Christians involved, disavowal of the Christian faith was added to the accusations; in doing so, the author linked sexual intercourse with a Jew/Jewess to heresy (which was punishable by burning). ${ }^{94}$

To prevent these and any other close contacts, canon law had as of 1215 required the Jews to wear a distinguishing marker. In western Europe, royal legislation took on the topic (see above), while in the Holy Roman Empire, secular legislators did not include any such regulations. ${ }^{95}$ However, both distinguishing garbs in general and the common Jewish attribute of the area specifically, the Jewish hat, appeared in customary law in a variety of contexts. The Sachsenspiegel mentions-rather neutrally-Jews and clerics who were excluded from the Imperial Peace if they bore arms and did not wear their hair "according to their law": the cleric's tonsure and the Jew's beard and hat, as the accompanying illustration shows. ${ }^{96}$ The Schwabenspiegel demanded that Jews wear the Jewish

91 Cf. Schmidt, "Judeneide," 101-2.

92 Cf. ibid., 103-4; Magin, "Wie es umb der iuden recht stet," 316-17.

93 Cf. Schnur, Juden in Frankfurt, 272-77.

94 Cf. Magin, “Wie es umb der iuden recht stet," 160-61, n. 162.

95 Cf. ibid., 158.

96 Heidelberger Sachsenspiegel, UB Heidelberg, Cod. Pal. germ. 164, https://digi.ub.uni-heidel berg.de/diglit/cpg164/0038; Magin, “Wie es umb der iuden recht stet," 158; Wenninger, "Juden in Bilderhandschriften." Sexual relationships between Jews and Christians did of course occur, cf. the examples given by Burghartz, "Juden-eine Minderheit;” Schnitzler, “'Contra Naturam';” and J. Müller, "Sexual Relationships between Christians and Jews in Medieval Germany, According to Christian Sources," in History of the Jewish People and Contemporary Jewish Society, vol. 2 of Iggud: Selected Essays in Jewish Studies, ed. G. Bacon et al. (Jerusalem: Gefen Books, 2009), 19-32. 
hat at all times and in all cities, while some copies of the Weichbildvulgata (Magdeburg, late thirteenth, early fourteenth century), and the legal code of Meißen (1357/87) that Jews were not allowed to leave the synagogue without wearing the Jewish hat, ${ }^{97}$ and the Jews of Augsburg had to wear the hat when selling their goods at the market (see below).

\section{Municipal Law}

The differentiation between customary law, municipal law, and laws of a secular ruler is vague at best-customary laws of a city were recorded from oral tradition, while codified municipal law was often issued by the lord of the town who would either pander to the citizens' wishes or put up a strict set of regulations to control them. Similar to customary law, the (anti-)Jewish topics dealt with in municipal law mainly concerned legal and economic issues, yet often with additional agendas of the citizenry as a emerging political player from the thirteenth century onwards. Regulations concerning Jewish behaviour and contact between Jews and Christians were imported from church law, such as the provision of the municipal law of Jihlava that forbade Jews and Christians to meet on Good Friday. ${ }^{98}$

These qualms were outrivalled in importance by concerns that had a more immediate impact on municipal politics: Jewish testimony, moneylending (with a particular focus on interest rates), and pawn-broking, many of which emerged from, or resulted in direct conflict with the respective town lord. Many of these regulations were not necessarily anti-Jewish in their primary intent but strove at monitoring and controlling the Jews' legal status and Jewish economic activities; generally, cities sought to achieve as encompassing a control as possible over all the diverse groups, citizens and others, living within the municipality. While in church law, ideas stemming from late antiquity were transported into the Late Middle Ages and beyond, municipal law often removed regulations that were no longer deemed relevant: for example, by the late thirteenth century, the banning of Jews from public offices had disappeared from municipal legislation, since these jobs were already filled with Christian office-holders anyway. ${ }^{99}$

97 Cf. Magin, “Wie es umb der iuden recht stet," 158-60.

98 Cf. Schreckenberg, Adversus Judaius, 3:144-45.

99 Cf. the examples provided by Haverkamp, "Jüdische Münzmeister,” and Wenninger, "Juden als Münzmeister.” 
Apart from (attempts at) undermining and mitigating the Statute of the Market and regulating the objects legal for pawning (see above), the limitation of the interest rate taken by Jews was a core issue for many cities. Since a diminished interest rate usually went against the interest of the respective ruler, cities went about in different ways: some tried to simply limit the interest rates, or at least limit compound interest, ${ }^{100}$ other cities took a more circumspect way, such as the citizens of Ulm, who sued their Jewish moneylenders on the basis of usury before the episcopal court. ${ }^{101}$ Among the many different efforts (and an equal variety of outcomes), a particularly drastic example shall illustrate the possibilities of municipal and limits of, in this case, ducal policy: in the wake of persecutions triggered by an alleged host desecration in 1338, and quickly expanding throughout Lower Austria and south of Bohemia and Moravia, the city of Vienna seized the chance to make use of the persecution to their own advantage. In return for protection, they forced the Jewish community to agree to a reduction of interest rates from eight (as granted in the ducal privilege from 1244) to three pennies per pound a week on loans for Viennese citizens. The Austrian dukes had to consent to the reduction due to the precarious situation the Jews in their territories were in, and the reluctance of the three leaders of the Jewish community is evident in the epithets the poor, the miserable, and the most ashamed they added to their signatures respectively. ${ }^{102}$

The ecclesiastical reservations against Jews testifying in Christian courts and their right to sue Christians were translated into everyday practice in many municipal legal codes, combining the church's idea of a Jew's testimony being worth less (or even invalid) than a Christian's with the citizenry's aim at strengthening the municipal jurisdiction over the Jews (and, in many cases, thus weakening the ruler's). While the general right of Jews to take Christians to court was rarely disputed, ${ }^{103}$ the Jews' position before court was weakened

100 E.g., Wiener Neustadt, Villach, cf. Wiedl, "Codifying Jews: Jews in Austrian Town Charters of the Thirteenth and Fourteenth Centuries," in Jews in Medieval Christendom: "Slay Them Not," ed. K. T. Utterback and M. L. Price (Leiden: Brill, 2013), 213; Frankfurt, cf. Schnur, Juden in Frankfurt, 456-58.

101 Cf. C. Scholl, Die Judengemeinde der Reichsstadt Ulm im späten Mittelalter: Innerjüdische Verhältnisse und christlich-jüdische Beziehungen in süddeutschen Zusammenhängen (Hannover: Hahnsche Buchhandlung, 2012), 184-85.

102 Cf. Wiedl, "Codifying Jews," 213-14.

103 An exception is the legal code for Freising (Bavaria), which in some of its copies state that if a Christ killed a Jew, the judge, not the Jew's relatives, should act as plaintiff, cf. Magin, "Wie es umb der iuden recht stet," 226-27. 
by, for example, exchanging Jewish with Christian witnesses, ${ }^{104}$ or demanding Jewish witnesses against a Jewish plaintiff. ${ }^{105}$ Only a few municipal legal codes included a prohibition of Jewish testimony, in most cases, this regulation is contradicted within the manuscript by ordinances allowing it (stemming from other referential texts); in neither of these codes, the inconsistencies within the text were commented on (if the author was even aware of them). ${ }^{106}$

Already in its early medieval councils, the church had cautioned Christians against Jewish food, and in connection with the cities' economic regulations, Jews were often banned from professions concerned with food, among which the selling of "Jewish" meat turned out to be the most disputed one. While some of the regulations merely intended to target a presumed Jewish competition and thus put additional charges on Jewish meat or ordered them to sell their meat at home, many cities arranged for a clear identification of the stalls where Jewish meat was sold: Jews were assigned a specific booth that was either at the fringe of the market, thus removing Jews from a major public space, and/ or used for the sale of "bad" meat (i.e., foul, trichinous meat or meat from sick or injured animals); if not, Jews were obliged to wear the Jewish hat (Augsburg) or had to alert potential Christian customers that they were about to buy "Jewish meat" (Bolzano). ${ }^{107}$ It has been debated whether these assignments automatically meant an anti-Jewish association with "rotten" and "foul," labelling Jewish meat as inferior not because of its actual quality but its provenance, or whether the permission to sell the meat at all (which was an exclusive right of the butchers') was in fact a privilege. ${ }^{108}$ In many towns, Jewish and Christian butchers cooperated: in Wroclaw, where in 1267 the synod had warned the Christians about the Jews' poisonous food, Jewish and Christian butchers had, after several conflicts, actually agreed on a collaboration that guaranteed both groups their safe income (which in return angered the bishop). ${ }^{109}$

104 Cf. Wiedl, “Codifying Jews,” 211-12 (Wiener Neustadt and St. Veit); Magin, “Wie es umb der iuden recht stet," 270 - 73 (Magdeburg).

105 Cf. Magin, "Wie es umb der iuden recht stet," 261-62 (Freising).

106 Cf. ibid., 268-270 (Meißen, Goslar).

107 Cf. Wiedl, “Codifying Jews,” 215-16.

108 Cf. Magin, "Wie es umb der iuden recht stet," 348; G. Maier, Wirtschaftliche Tätigkeitsfelder von Juden im Reichsgebiet (ca. 1273 bis 1350) (Trier: Kliomedia, 2010).

109 Cf. ibid., 68-69. 


\section{Conclusion}

It is tantamount to a commonplace to stress that medieval anti-Jewish thoughts and actions were prevalent at all times and in all parts of society, to which medieval legislation, or rather its manifold variations, was but one contributor. For the populace, anti-Jewish narratives and visual images disseminated stereotypes and prejudices much more efficiently and engrained a deep-rooted mistrust into the common mind-set, however, the influence of medieval legislation should not be underestimated. Secular, municipal, and-to a certain extent-customary laws provided the framework inside of which medieval Jewish life could exist in Christian-dominated territories. Its anti-Jewish propensities varied greatly: while in the territories of the Holy Roman Empire, ideas of (imperial) protection and the financial gain from prospering Jewish communities for a long time prevented anti-Jewish thought from entering legislation (which, however, did not hinder many rulers to participate in the loot after persecutions), the Jews of England and France, under much tighter royal control, were subjected to a royal legislation that showed a stronger influence of canon and church law. Church law was, despite its limited impact on actual Jewish living conditions and daily life, one of the main mediums by which anti-Jewish ideas could persist from antiquity throughout the Middle Ages (and beyond), and worked as a catalyst for more commonly understandable narratives (e.g., the transubstantiation dogma and the ensuing host desecration accusations). Furthermore, medieval anti-Jewish laws, even if not implemented at the time, made sure that stereotypes not only prevailed but were deeply anchored in the legislation of both the church and the emerging modern states; they prepared the ground for policies of later centuries, such as the church's demands of segregation and separation of Jewish and Christian living spaces, which, while only rarely carried out in the Middle Ages, were translated into the reality of the ghettos from the sixteenth century onwards.

Birgit Wiedl is a research fellow at the Institute for Jewish History in Austria (St. Pölten) and a lecturer at the Universities of Salzburg and Klagenfurt. She is the co-editor of the Regesten zur Geschichte der Juden in Österreich (four volumes to date) and specialises in medieval Jewish history, Jewish-Christian interaction, and medieval anti-Judaism, on which she has published extensively. The article was funded by the Austrian Science Fund (FWF): P 32396 and its preceding projects. 


\section{Bibliography}

\section{Primary Sources}

Birds' Head Haggadah, c. 1300. The Israel Museum, Jerusalem, B46.04.0912, 180/057. https://www.imj.org.il/en/collections/199815.

Corpus der Quellen zur Geschichte der Juden im spätmittelalterlichen Reich, coordinated by Alfred HAVerkamp and Jörg MülLer, University of Trier, from 2011 onwards. http://www. medieval-ashkenaz.org/quellen/1273-1347/sk01.html.

Große Heidelberger Liederhandschrift (Codex Manesse), c. 1300-1340. Universitätsbibliothek Heidelberg, Cod. Pal. germ. 848. https://digi.ub.uni-heidelberg.de/diglit/cpg848/0705.

Heidelberger Sachsenspiegel. Universiätsbibliothek Heidelberg, Cod. Pal. germ. 164. http:// digi.ub.uni-heidelberg.de/diglit/cpg164/0040.

Petrus Vernerabilis. Against the Inveterate Obduracy of the Jews. Translated and annotated by Irven M. Resnick. Washington: Catholic University of America Press, 2013.

Schwabenspiegel, c. 1425/50. KBR, Royal Library of Belgium, ms. 14689-91. https://uurl.kbr. be/1065739.

\section{Secondary Sources}

Abulafia, Anna Sapir. Christian-Jewish Relations, 1000-1300: Jews in the Service of Medieval Christendom. London: Routledge, 2011.

Abulafia, Anna Sapir. "Gratian and the Jews." Jaarboek Thomas Instituut te Utrecht 36 (2017): $9-39$.

Backhaus, Fritz. "Die Hostienschändungsprozesse von Sternberg (1492) und Berlin (1510) und die Ausweisung der Juden aus Mecklenburg und der Mark Brandenburg." Jahrbuch für Brandenburgische Landesgeschichte 39 (1988): 7-26.

Bale, Anthony Paul. The Jew in the Medieval Book: English Antisemitisms, 1350-1500. Cambridge: Cambridge University Press, 2006.

Baumgarten, Elisheva. Practicing Piety in Medieval Ashkenaz: Men, Women, and Everyday Religious Observance. Philadelphia: University of Pennsylvania Press, 2014.

Becker, Hans-Jürgen. "Die Stellung des kanonischen Rechts zu den Andersgläubigen: Heiden, Juden und Ketzer." In Wechselseitige Wahrnehmung der Religionen im Spätmittelalter und in der Frühen Neuzeit, edited by Ludger Grenzmann, Thomas Haye, Nikolaus Henkel, and Thomas Kaufmann, 100-23. Berlin: De Gruyter, 2009.

Berend, Nora. At the Gate of Christendom: Jews, Muslims and 'Pagans' in Medieval Hungary, c. 1000-c. 1300. Cambridge: Cambridge University Press, 2001.

Boddens Hosang, F. J. E. Establishing Boundaries: Christian-Jewish Relations in Early Council Texts and the Writings of Church Fathers. Leiden: Brill, 2010.

Brugger, Eveline. "Von der Ansiedlung bis zur Vertreibung: Juden in Österreich im Mittelalter." In Geschichte der Juden in Österreich, edited by Eveline Brugger, Martha Keil, Alfred Lichtblau, Christoph Lind, and Barbara Staudinger, 123-227. Wien: Ueberreuter, 2013. 
Brugger, Eveline, and Birgit Wiedl. Von den Anfängen bis 1338. Vol. 1 of Regesten zur Geschichte der Juden in Österreich im Mittelalter. Innsbruck: StudienVerlag, 2005.

Burghartz, Susanna. "Juden - eine Minderheit vor Gericht (Zürich 1378-1436).” In Spannungen und Widersprüche: Gedenkschrift für František Graus, edited by Susanna Burghartz et al., 229-44. Sigmaringen: Jan Thorbecke, 1992.

Chazan, Robert. The Jews of Medieval Western Christendom, 1000-1500. Cambridge: Cambridge University Press, 2006.

Chazan, Robert. Medieval Stereotypes and Modern Antisemitism. Berkeley: University of California Press, 1997.

Chazan, Robert. Reassessing Jewish Life in Medieval Europe. Cambridge: Cambridge University Press, 2010.

Cluse, Christoph. "Jewish Moneylending in Dominican Preaching, Confession, and Counselling: Some Examples from Later Medieval Germany." In Dominikaner und Juden: Personen, Konflikte und Perspektiven vom 13. bis zum 20. Jahrhundert/Dominicans and Jews: Personalities, Conflicts, and Perspectives from the $13^{\text {th }}$ to the $20^{\text {th }}$ Century, edited by Elias H. Füllenbach and Gianfranco Miletto, 195-23. Berlin: De Gruyter, 2015.

Cluse, Christoph. “'Töte sie nicht!' Echos der Augustinischen Theologie über die jüdische 'Zeugenschaft' im Mittelalter." In Augustinus - Christentum - Judentum. Ausgewählte Stationen einer Problemgeschichte, edited by Christof Müller and Guntram Förstner, 113-55. Würzburg: Augustinus bei echter, 2018.

Cluse, Christoph. "Zum Zusammenhang von Wuchervorwurf und Judenvertreibung im 13. Jahrhundert." In Judenvertreibungen in Mittelalter und Früher Neuzeit, edited by Friedhelm Burgard, Alfred Haverkamp, and Gerd Mentgen. Hannover: Hahnsche Buchhandlung, 1999.

Cohen, Jeremy. Living Letters of the Law: Ideas of the Jew in Medieval Christianity. Berkley: University of California Press, 1999.

Dorin, Rowan W. "Canon Law and the Problem of Expulsion: The Origin and Interpretation of Usurarum voraginem (VI 5.5.1)." Zeitschrift der Savigny-Stiftung für Rechtsgeschichte: Kanonistische Abteilung 99, no. 1 (2013): 129-61.

Fidora, Alexander. "Latin Talmud and the Extension of Papal Jurisdiction over Jews." medieval worlds: comparative \& interdisciplinary studies 11 (2020): 152-64.

Fogle, Lauren. The King's Converts: Jewish Conversion in Medieval London. Lanham: Lexington Books, 2019.

Freidenreich, David M. "Sharing Meals with Non-Christians in Canon Law Commentaries, Circa 1160-1260: A Case Study in Legal Development.” Medieval Encounters 14 (2008): 41-77.

Gilomen, Hans-Jörg. "Spätmittelalterliche Siedlungssegregation und Ghettoisierung, insbesondere im Gebiet der heutigen Schweiz." In Abgrenzungen - Ausgrenzungen in der Stadt und um die Stadt, vol. 3 of Stadt- und Landmauern, edited by Institut für Denkmalpflege an der ETH Zürich, 85-106. Zürich: Hochschulverlag AG an der ETH Zürich, 1999.

Goldin, Simha. Apostasy and Jewish Identity in High Middle Ages Northern Europe: 'Are you still my brother?'. Translated by Jonathan Chipman. Manchester: Manchester University Press, 2014. 
Grebner, Gundula. "Haltungen zum Judeneid: Texte und Kontexte der Frankfurter Eidesformeln im 14. und 15. Jahrhundert.” In '...Ihrer Bürger Freiheit:' Frankfurt am Main im Mittelalter, edited by Heribert Müller, 141-73. Frankfurt am Main: Waldemar Kramer, 2004.

Haverkamp, Alfred. "Baptised Jews in German Lands during the Twelfth Century." In Jews and Christians in Twelfth-Century Europe, edited by Michael A. Signer and John Van Engen, 255-310. Notre Dame: University of Notre Dame Press, 2001.

Haverkamp, Eva. "Jewish Images on Christian Coins: Economy and Symbolism in Medieval Germany." Jews and Christians in Medieval Europe: The Historiographical Legacy of Bernhard Blumenkranz, edited by Philippe Buc, Martha Keil, and John V. Tolan, 189-226. Turnhout: Brepols, 2016.

Haverkamp, Eva. "Jüdische Münzmeister und ihre Münzen im Kontext von Handel und Geldhandel." In Geprägte Bilderwelten der Romanik: Münzkunst und Währungsräume zwischen Brixen und Prag, edited by Florian Hofer, Armin Torggler, Daniele Pizzinini, and Alexandra Hylla, 155-91. Bolzano: Athesia Tappeiner, 2017.

Heil, Johannes. "Die propagandistische Vorbereitung des Ghettos: Diskussionen um Judenquartiere." In Frühneuzeitliche Ghettos in Europa im Vergleich, edited by Fritz Backhaus, Gisela Engel, Gundula Grebner, and Robert Liberles, 149-70. Berlin: trafo, 2012.

Heil, Johannes. "Gottesfeinde"-"Menschenfeinde": Die Vorstellung von jüdischer Weltverschwörung (13. bis 16. Jahrhundert). Essen: Klartext, 2006.

Heng, Geraldine. England and the Jews: How Religion and Violence Created the First Racial State in the West. Cambridge: Cambridge University Press, 2019.

Heng, Geraldine. The Invention of Race in the European Middle Ages. Cambridge: Cambridge University Press, 2018.

Hillaby, Joe G., and Caroline Hillaby. The Palgrave Dictionary of Medieval Anglo-Jewish History. London: Palgrave Macmillan, 2013.

Honemann, Volker. "Die Sternberger Hostienschändung und ihre Quellen.” Literaturlandschaften: Schriften zur deutschsprachigen Literatur im Osten des Reiches, edited Volker Honemann et al., 187-216. Frankfurt am Main: Peter Lang, 2008.

Hruza, Karel. "Anno domini 1385 do burden die iuden ... gevangen. Die vorweggenommene Wirkung skandalöser Urkunden König Wenzels (IV.)." In Wege zur Urkunde, Wege der Urkunde, Wege der Forschung: Beiträge zur europäischen Diplomatik des Mittelalters, edited by Karel Hruza and Paul A. Herold, 117-67. Wien: Böhlau, 2005.

Jordan, William Chester. The Apple of His Eye: Converts from Islam in the Reign of Louis IX. Princeton: Princeton University Press, 2019.

Jordan, William Chester. The French Monarchy and the Jews: From Philip Augustus to the Last Capetians. Philadelphia: University of Pennsylvania Press, 1989.

Jütte, Robert. "Stigma-Symbole: Kleidung als identitätsstiftendes Merkmal bei spätmittelalterlichen und frühneuzeitlichen Randgruppen (Juden, Dirnen, Aussätzigen, Bettler)." Saeculum 44, no. 1 (1993): 65-89.

Keil, Martha. "Heilige Worte, Schriften des Abscheus-der Umgang mit Büchern als Paradigma des jüdisch-christlichen Spannungsverhältnisses." In Text als Realie, edited by Karl Brunner and Gerhard Jaritz, 49-61. Wien: Austrian Academy of Sciences Press, 2003.

Keil, Martha. “Das 'Ritual des ersten Lernens' zu Schawuot im Mittelalter.” David. Jüdische Kulturzeitschrift 18, no. 69 (2006): 5-7. 
Kogmann-Appel, Katrin. A Mahzor from Worms: Art and Religion in a Medieval Jewish Community. Cambridge: Harvard University Press, 2012.

Lehnertz, Andreas. Judensiegel im spätmittelalterlichen Reichsgebiet: Beglaubigungstätigkeit und Selbstrepräsentation von Jüdinnen und Juden. 2 vols. Wiesbaden: Harrassowitz, 2020.

Lehnertz, Andreas. "The Erfurt Judeneid between Pragmatism and Ritual: Some Aspects of Christian and Jewish Oath-Taking in Medieval Germany." In Ritual Objects in Ritual Contexts, edited by Claudia D. Bergemann and Maria StüRzebeCHeR, 12-31. Erfurt: Bussert \& Stadeler, 2020.

Lipton, Sara. Dark Mirror: The Medieval Origins of Anti-Jewish Iconography. New York: Metropolitan Books, 2014.

Lopez, Julia Costa. "Beyond Eurocentrism and Orientalism: Revisiting the Othering of Jews and Muslims through medieval canon law." Review of International Studies 42, no. 3 (2016): $450-70$.

Lotter, Friedrich. “Die Juden im Decretum Gratiani." Aschkenas 28, no. 2 (2018): 217-81.

Lotter, Friedrich. "Die Juden in den späteren kanonistischen Rechtssammlungen." Aschkenas 28, no. 2 (2018): $282-336$.

Lotter, Friedrich. "Die Stellung der Juden im Merowingerreich nach dem Zeugnis der Synodalakten." Aschkenas 28, no. 2 (2018): 175-216.

Magin, Christine. "'Waffenrecht' und 'Waffenverbot' für Juden im Mittelalter: Zu einem Mythos der Forschungsgeschichte." Aschkenas 13, no. 1 (2003): 17-33.

Magin, Christine. "Wie es umb der iuden recht stet": Der Status der Juden in spätmittelalterlichen deutschen Rechtsbüchern. Göttingen: Wallstein, 1999.

Maier, Gregor. Wirtschaftliche Tätigkeitsfelder von Juden im Reichsgebiet (ca. 1273 bis 1350). Trier: Kliomedia, 2010.

Mentgen, Gerd. “Judeneid.” Handwörterbuch der deutschen Rechtsgeschichte, 2:1409-11. Berlin: Erich Schmidt, 2011.

Mikosch, Gunnar. Von alter ê und ungetriuwen Juden: Juden und Judendiskurse in den deutschen Predigten des 12. und 13. Jahrhunderts. München: Wilhelm Fink, 2010.

Müller, Jörg. "Sexual Relationships between Christians and Jews in Medieval Germany, According to Christian Sources." In History of the Jewish People and Contemporary Jewish Society, vol. 2 of Iggud: Selected Essays in Jewish Studies, edited by Gershon Bacon, Albert Baumgarten, Jacob Barnai, Chaim Waxman, and Israel J. Yuval, 19-32. Jerusalem: Gefen Books, 2009.

Müller, Jörg R. "Zur Verpfändung sakraler Kultgegenstände an Juden im mittelalterlichen Reich: Norm und Praxis." In Pro multis beneficiis: Festschrift für Friedhelm Burgard: Forschungen zur Geschichte der Juden und des Trierer Raums, edited by Sigrid Hirbodian, Sabine Klapp, Jörg R. Müller, and Christian Jörg, 179-204. Trier: Kliomedia, 2012.

Posselt, Bernd. Konzeption und Kompilation der Schedelschen Weltchronik. Wiesbaden: Harrassowitz, 2015.

Raveaux, Thomas. "Das Judenbild bei Augustinus." In Augustinus - Christentum - Judentum: Ausgewählte Stationen einer Problemgeschichte, edited by Christof Müller and Guntram Förstner, 49-80. Würzburg: Augustinus bei echter, 2018.

Resnick, Irven M. "Dietary Laws in Jewish-Christian Polemics: A Survey." Studies in Jewish-Christian Relations 6 (2011): 1-15. 
Resnick, Irven M. "Peter the Venerable on the Talmud, the Jews, and Islam." Medieval Encounters 24 (2018): 510-29.

Richtscheid, René. “Judenbetreffe in Synodal- und Konzilsstatuten (1237-1347).” Corpus der Quellen zur Geschichte der Juden im spätmittelalterlichen Reich, issued 2011. Accessed October 27, 2020. http://www.medieval-ashkenaz.org/SK01/einleitung.html.

Rowe, Nina. The Jew, the Cathedral, and the Medieval City: Synagoga and Ecclesia in the Thirteenth Century. Cambridge: Cambridge University Press, 2014.

Schima, Stefan. "Die Entwicklung des kanonischen Zinsverbots. Eine Darstellung unter besonderer Berücksichtigung der Bezugnahmen zum Judentum." Aschkenas 20 (2010): $239-79$.

Schmidt, Annette. "so dir got helfe: Die Judeneide." In Juden in der deutschen Literatur des Mittelalters. Religiöse Konzepte-Feindbilder-Rechtfertigungen, edited by Ursula Schulze, 87-105. Tübingen: Max Niemeyer, 2002.

Schnitzler, Nobert. “'Contra Naturam': Sexuelle Devianz und jüdisch-christliche Koexistenz im Mittelalter." In Wechselseitige Wahrnehmung der Religionen im Spätmittelalter und in der Frühen Neuzeit, edited by Ludger Grenzmann, Thomas Haye, Nikolaus Henkel, and Thomas Kaufmann, 251-81. Berlin: De Gruyter, 2009.

Schnur, David. Die Juden in Frankfurt am Main und in der Wetterau im Mittelalter: Christlich-jüdische Beziehungen, Gemeinden, Recht und Wirtschaft von den Anfängen bis um 1400. Wiesbaden: Kommission für die Geschichte der Juden in Hessen, 2017.

Scholl, Christian. Die Judengemeinde der Reichsstadt Ulm im späten Mittelalter: Innerjüdische Verhältnisse und christlich-jüdische Beziehungen in süddeutschen Zusammenhängen. Hannover: Hahnsche Buchhandlung, 2012.

Schreckenberg, Heinz. Die christlichen Adversus-Judaeos-Texte und ihr literarisches und historisches Umfeld. 3 vols. Frankfurt/Main: Peter Lang, 1999.

Shachar, Isaiah. The Judensau: A Medieval Anti-Jewish Motif and its History. London: Warburg Institute, 1974.

Shatzmiller, Joseph. "Church Articles: Pawns in the Hands of Jewish Moneylenders." In Wirtschaftsgeschichte der mittelalterlichen Juden: Fragen und Einschätzungen, edited by Michael Toch and Elisabeth Müller-Luckner, 93-102. München: Oldenbourg, 2008.

Shatzmiller, Joseph. Cultural Exchange: Jews, Christians, and Art in the Medieval Marketplace. Princeton: Princeton University Press, 2013.

Shatzmiller, Joseph. "Jewish Converts to Christianity in Medieval Europe 1200-1500." In Cross Cultural Convergences in the Crusader Period: Essays Presented to Aryeh Grabois on His Sixty-fifth Birthday, edited by Michael Goodich, Sophia Menache, and Sylvia Schein, 297-318. New York: Peter Lang, 1999.

Simonsohn, Shlomo. The Apostolic See and the Jews: Documents, 492-1404. Toronto: Pontifical Institute of Mediaeval Studies, 1988.

Stacey, Robert C. "King Henry III and the Jews." In Jews in Medieval Christendom: "Slay Them Not," edited by Kristine T. Utterback and Merrall Llewelyn Price, 117-28. Leiden: Brill, 2013.

Tartakoff, Paola. Conversion, Circumcision, and Ritual Murder in Medieval Europe. Philadelphia: University of Pennsylvania Press, 2020.

Toch, Michael. Die Juden im mittelalterlichen Reich. München: Oldenbourg, 2013.

Voltelini, Hans. "Der Wiener und Kremser Judeneid." Mitteilungen des Vereins für Geschichte der Stadt Wien 12 (1932): 64-70. 
Weber, Annette. "Glaube und Wissen-Ecclesia et Synagoga." In Wissenspopularisierung: Konzepte der Wissensverbreitung im Wandel, edited by Carsten Kretschmann, 89-126. Berlin: Akademie Verlag, 2003.

Wenninger, Markus J. “'als etlich kristen lüt...mit dien Juden getanzet hant': Über die Teilnahme von Christen an jüdischen Festen im Mittelalter." Aschkenas 26, no. 1 (2016): 37-67.

Wenninger, Markus J. “Juden als Münzmeister, Zollpächter und fürstliche Finanzbeamte im mittelalterlichen Aschkenas." In Wirtschaftsgeschichte der mittelalterlichen Juden: Fragen und Einschätzungen, edited by Michael Toch, 121-89. München: Oldenbourg, 2008.

Wenninger, Markus J. "Die Juden in den Bilderhandschriften des Sachsenspiegels." In Integration und Ausgrenzung: Studien zur deutsch-jüdischen Literatur- und Kulturgeschichte von der Frühen Neuzeit bis zur Gegenwart. Festschrift für Hans Otto Horch, edited by Mark H. Gelber, Jakob Hessing, and Robert Jütte, 2-18. Tübingen: Max Niemeyer, 2009.

Wenninger, Markus J. "Von jüdischen Rittern und anderen waffentragenden Juden im mittelalterlichen Deutschland.” Aschkenas 13, no. 1 (2003): 35-82.

Wiedl, Birgit. "Anti-Jewish Polemics in Business Charters from Late Medieval Austria." Medieval Worlds: Comparative \& Interdisciplinary Studies 7 (2018): 61-79.

Wiedl, Birgit. "Codifying Jews: Jews in Austrian Town Charters of the Thirteenth and Fourteenth Centuries." In Jews in Medieval Christendom: "Slay Them Not," edited by Kristine T. Utterback and Merrall Llewelyn Price, 201-22. Leiden: Brill, 2013.

Wiedl, Birgit. "Jews and Anti-Jewish Fantasies in Christian Imagination in the Middle Ages." In Imagination and Fantasy in the Middle Ages and Early Modern Time: Projections, Dreams, Monsters, and Illusions, edited by Albrecht Classen, 573-606. Berlin: De Gruyter, 2020.

Wiedl, Birgit. "Laughing at the Beast: The Judensau: Anti-Jewish Propaganda and Humor from the Middle Ages to the Early Modern Period." Laughter in the Middle Ages and Early Modern Times: Epistemology of a Fundamental Human Behavior, its Meaning, and Consequences, edited by Albrecht Classen, 325-64. Berlin: De Gruyter, 2010.

Wiedl, Birgit. "Sacred Objects in Jewish Hands: Two Case Studies." In Jews and Christians in Medieval Europe: The Historiographical Legacy of Bernhard Blumenkranz, edited by Philippe Buc, Martha Keil, and John V. Tolan, 57-77. Turnhout: Brepols, 2016.

Wiedl, Birgit. “...und kam der jud vor mich ze offens gericht. Juden und (städtische) Gerichtsobrigkeiten im Spätmittelalter." Mediaevistik. Internationale Zeitschrift für Interdisziplinäre Mittelalterforschung 28/2015 (2016): 243-68. 
